\title{
Low-Income Access to Employer-Based Transit Benefits: Evidence from 10 Large Metropolitan Regions
}

\author{
Andrea Hamre \\ Virginia Tech Alexandria Center
}

\begin{abstract}
While national aggregate statistics suggest employer-based transit subsidies may be inaccessible to the majority of the working poor, this is the first study to investigate the subject with disaggregate data while controlling for additional factors. This study uses household travel surveys for 10 of the largest Metropolitan Planning Organizations, grouped into seven cases. In each case, the share of workers offered an employer-based transit subsidy is lowest for workers in the lowest income quintile. Binary logistic regression results for the odds of being offered an employer-based transit subsidy are presented for two cases, Washington, DC, and Denver, CO, and the results largely confirm that low-income workers are less likely to have access to employer-based transit subsidies than workers in higher income groups, even after controlling for other relevant worker and employer characteristics. These findings may be relevant to policy makers interested in supporting affordable access to opportunities.
\end{abstract}

Keywords: commuter benefits, affordability, household travel surveys

\section{Introduction}

Affordable access is of critical importance to the working poor, for whom transport costs represent a significant burden across many measures. The working poor are less likely to drive to work and more likely to use commute alternatives than the population as a whole (Bureau of Transportation Statistics 2016), and in the past have spent a higher share of their income on commuting (Bureau of Transportation Statistics 2003). Travel costs generally represent an "overwhelming constraint" (Clifton and Lucas 2004) and "heavy financial burden" (Agrawal et al. 2011) for those with low incomes, impacting the type and extent of daily travel as well

\footnotetext{
(C) 2019 Andrea Hamre

https://doi.org/10.5038/2642-6188.1.1.1

ISSN: 2642-6188 | Licenced under Creative Commons License Attribution - Noncommercial 4.0

The Journal of Transportation Demand Management is published by the Center for Urban Transportation Research at the University of South Florida
} 
as opportunities for social mobility (Bouchard 2015; Stolper and Rankin 2016). The poor tend to own fewer vehicles, make fewer trips, travel shorter distances, and use slower and less expensive forms of public transport (Bureau of Transportation Statistics 2016; Federal Highway Administration 2011; Clifton and Lucas 2004; Sanchez et al. 2007; Agrawal et al. 2011; Tomer 2011; Clark 2017). While public transport has the capacity to serve as "an effective money-saving tool" (Ferrell 2015; see also Litman 2018), the poor have had to contend with an increase in transit costs that has outpaced the increase in personal vehicle cost (Bureau of Transportation Statistics 2016, Figure 5-22). Indeed, transit fare affordability was the largest problem cited by low-income New Yorkers in a recent advocacy-based survey about the subway system (Stolper and Rankin 2016). In addition, low-income households often face tradeoffs in consumption versus accessibility poverty, whereby "many of the most vulnerable families must choose between spending on basic necessities or important trips that connect them to the workforce and social supports" (Stolper and Rankin 2016; see also Agrawal et al. 2011 and Deka 2004). Affordable transport has received less attention than other challenges faced by the poor (Agrawal et al. 2011), but there is growing recognition that transport should be considered alongside health, education, and housing as a key dimension of welfare (Jeekel and Martens 2017).

This study focuses on disparate access to employer-based transit subsidies across income groups, and the findings may hold relevance for policy deliberations regarding commuter benefit ordinances, which have typically not emphasized affordable access for the working poor. According to the Bureau of Labor Statistics National Compensation Survey, $2 \%$ of civilian workers in the lowest wage quartile have subsidized commuting for public transport and vanpooling, compared to 14\% for workers in the highest wage quartile (Bureau of Labor Statistics 2018, Table 40). 'While these national statistics suggest disparities exist in subsidized commuting across income groups, this study investigates the subject with disaggregate data and controls for additional worker and employer characteristics. The study groups household travel surveys for 10 of the largest Metropolitan Planning Organizations in the United States into seven cases, and presents the distribution of employer-based transit benefits for each case. Subsequently, binary logistic regression is used to estimate the likelihood of being offered an employer-based transit subsidy for two cases. Following a brief overview of the literature on commuter benefits as it relates to low-income workers and affordable access, an empirical analysis investigates the association between income and the offer of an employer-based transit benefit.

\section{Equity Impacts in the Commuter Benefits Literature}

While congestion and environmental impacts have been a primary focus of the commuter benefits literature, there has also been a long-standing appreciation of distributional and equity impacts. In an early study on commuter benefits, Segelhorst and Kirkus (1973) described how car parking subsidies tend to benefit high-income auto commuters while low-income transit commuters incur added congestion costs, leading to an outcome where "net incomes become more unequally distributed." Many studies have acknowledged the potential for public transport subsidies to offer equity gains for low-income workers, who tend to ride public transport at higher rates than others. For example, Root described how "existing bus users would benefit from service enhancements" spurred by the increased transit patronage likely to result from subsidies for transit (2001).

A large body of scholarship by Donald Shoup and Richard Willson has focused on the relationship between employer subsidies for car parking and commuter travel behavior. Alongside discussions of congestion, air pollution, and energy use, these authors have highlighted the tendency for car parking subsidies to benefit higher-income groups (Willson and Shoup 1990). In Parking Cash Out (2005), Shoup devoted attention to the

'In the National Compensation Survey, subsidized commuting refers to "full or partial payment for the cost of an employee's commute to work via public transportation, a company sponsored van pool, discount subway fares, or bus tokens" (Bureau of Labor Statistics 2018). 
ways in which this mechanism may benefit traditionally disadvantaged groups, such as low-income workers, who tend to commute to work in single-occupancy vehicles at lower rates. He described parking cash out as a way to promote "both tax equity and transportation justice" and argued that "avoiding bias in transportation policy is simple transportation justice" (Shoup 2005).

Removal of car parking subsidies may nevertheless negatively impact lower-income workers in certain circumstances. In a study of stated responses to parking pricing for the Washington, DC, area, Kuppam and colleagues cautioned that pricing levels should aim to achieve "desired transportation impacts...without causing hardship to lower income populations" (1998). Similarly, when studying transportation demand management strategies in Portland, OR, Bianco described the challenge of effectively influencing workers who can afford to pay increased parking prices without reaching such high levels that "the resulting inequity for lower-income groups [would outweigh] the societal gain of the mode shift" (2000). In a study of road and parking pricing impacts on commuter mode choice in Vancouver, BC, Washbrook and colleagues found price elasticities of demand peaked in middle income ranges; they attributed the relative lack of price sensitivity of low-income workers to their limited choice sets, and cautioned that these workers could be pressured to either pay the charges or shift to low-quality public transport (2006).

\section{Empirical Strategy}

This study's principal research question asks, Does the likelihood of being offered an employer-based transit subsidy vary across income groups? While aggregate data sources, such as the National Compensation Survey, suggest disparities exist in subsidized commuting for public transport and vanpooling across income groups, this study investigates the subject with disaggregate data and controls for additional worker and employer characteristics. The associated hypothesis is as follows: income is positively associated with the likelihood of being offered an employer-based transit subsidy, even after controlling for factors such as car parking subsidies, employer type, employer location, occupation, and work schedule. In particular, it is expected that low-income workers will be less likely to have access to employer-based transit subsidies than workers in higher income categories.

Large metropolitan areas tend to offer diverse transport systems and services and are more likely to have significant numbers of employers offering commuter benefits for public transport. In addition, large metropolitan areas are likely to have Metropolitan Planning Organizations (MPOs) with the resources to conduct and compile regional household travel surveys, which offer the best regionally representative disaggregate data about employer-based transit benefits currently available. ${ }^{2}$ In particular, this study utilizes data for 10 of the nation's 22 largest MPOs. Across the 10 MPOs, there were six different survey formats. ${ }^{3}$ To account for survey format variation and enable the use of appropriate survey weights, the $10 \mathrm{MPO}$ were grouped into seven cases: (1) Atlanta (ATL); (2) Baltimore and Washington, DC (BAL \& DC); (3) Denver (DEN); (4) Los Angeles and San Diego (LA \& SD); (5) New York and Newark (NY \& NJ); (6) Philadelphia (PHL); and (7) San Francisco (SF). These groupings are based on MPOs that share a geographic border and travel survey format. Table 1 lists the MPOs and household travel surveys used.

${ }^{2}$ The nationally representative 2001, 2009, and 2017 National Household Travel Surveys did not collect information about employer-based transit benefits.

${ }^{3}$ The Washington, DC, and Baltimore, MD, MPOs collaborated on their 2007-2008 surveys, while the Newark, NJ, and New York, NY, MPOs jointly administered their 2010-2011 survey, and the California MPO samples were derived from the same 2010-2012 statewide survey. 
TABLE 1.

List of MPOs and Corresponding Travel Surveys Included in the Study

\begin{tabular}{|l|c|r|l|}
\hline \multicolumn{1}{|c|}{ MPO } & Major City & 2010 Population & \multicolumn{1}{c|}{ Survey Year/Type } \\
\hline Atlanta Regional Commission & Atlanta, GA & $4,818,052$ & $2011 /$ Regional \\
\hline Baltimore Regional Transportation Board & Baltimore, MD & $2,684,661$ & $2007-2008 /$ Regional \\
\hline Delaware Valley Regional Planning Commission & Philadelphia, PA & $5,626,318$ & $2012-2013 /$ Regional \\
\hline Denver Regional Council of Governments & Denver, CO & $2,827,082$ & $2009-2010 /$ Regional \\
\hline Metropolitan Transportation Commission & San Francisco, CA & $7,150,828$ & $2010-2012 /$ State \\
\hline National Capital Region Transportation Planning Board & Washington, DC & $5,068,737$ & $2007-2008 /$ Regional \\
\hline New York Metropolitan Transportation Council & New York, NY & $12,367,508$ & $2010-2011 /$ Regional \\
\hline North Jersey Transportation Planning Authority & Newark, NJ & $6,579,801$ & $2010-2011 /$ Regional \\
\hline San Diego Association of Governments & San Diego, CA & $3,095,271$ & $2010-2012 /$ State \\
\hline Southern California Association of Governments & Los Angeles, CA & $18,051,203$ & $2010-2012 /$ State \\
\hline
\end{tabular}

Note: Compiled using the Federal Highway Administration's Metropolitan Planning Organization Database (2017). Data for ATL, LA \& SD, and SF were obtained using the National Renewable Energy Laboratory's Transportation Secure Data Center (NREL 2017). Data for BAL \& DC, and DEN, were obtained by request (DRCG 2010; BRTB 2008; NCRTPB 2008). Data for NY \& NJ, and PHL, were obtained through open-access downloads from MPO websites (NYMTC 2011; DVRPC 2013).

Jurisdictions in three of the included MPOs (San Francisco and Berkeley in the Bay Area, Washington, DC, and New York, NY) have passed transit benefit ordinances over the past decade. The California survey used for the San Francisco MPO was conducted after implementation of transit benefit ordinances in that region, while the surveys for Washington, DC, and New York, NY, were both conducted before implementation of transit benefit ordinances in those cities. Thus, the study mainly looks at employer-based transit benefit offerings in the absence of transit benefit ordinances, with the exception of the findings for the San Francisco sample. This study may therefore have some relevance for cities or regions contemplating commuter benefit ordinances.

Binary logistic regression was used, with standard errors robust to clusters at the household level, to model the likelihood of being offered an employer-based transit subsidy. Logistic regression is appropriate for a limited dependent variable that takes on only two values, as is the case for the transit subsidy offering. The modeled relationship may be summarized as follows:

$\operatorname{Pr}($ employer-based transit subsidy $=1)=\Theta\left(\beta_{0}+\beta_{1}\right.$ employee income $+\beta_{2}$ car parking subsidy $+\beta_{3}$ employer location $+\beta_{4}$ employer type $+\beta_{5}$ schedule type $+\beta_{6}$ occupation $+\varepsilon$ )

The six survey formats varied in the availability and categorization of information about factors of interest. As a result, this study highlights patterns across the cases in the sign and significance of the coefficients, but is not designed for direct comparisons about the magnitudes of estimated effects. Table 2 details how information about employer-based transportation subsidies was collected across the various surveys. These surveys all collected binary information about whether subsidies were offered, but no information about their monetary value. A binary transit subsidy variable was created for each region/set of regions. The share of workers who did not know whether they were offered an employer-based transit subsidy varied as follows: ATL 8\%; BAL \& DC (DK not an option, 11\% listed NA); DEN 4\%; PHL 41\%; and NY \& NJ 2\%. Employer-based transit subsidy information was collected from all workers, except in the case of the California statewide survey, which only collected that information from workers who had taken at least one transit trip in the prior week. A binary parking subsidy variable was also created for each region, where possible. A combined "parking subsidy" 
category was created where both free and subsidized parking categories were included (ATL, BAL \& DC, PHL). For NY \& NJ, workers were able to list up to three employer transportation benefits, and all responses were incorporated into the transit and parking subsidy binary variables. A parking subsidy variable could not be included for LA \& SD or SF as the California statewide survey did not collect information in the person file about employer-based parking subsidies. Hamre (2018) provides detailed information about the preparation of the other variables used in the study.

\section{TABLE 2.}

Survey Formats for Employer-Based Transportation Subsidies

\begin{tabular}{|l|l|}
\hline \multicolumn{1}{|c|}{ MPO } & \multicolumn{1}{c|}{ Survey Question Regarding Transit Subsidies } \\
\hline ATL & $\begin{array}{l}\text { Employer Subsidizes Transit: 1: Yes; 2: No; 8: DK; 9: RF } \\
\text { Employer Provides Parking: 1: Yes; 2: No; 8: DK; 9: RF } \\
\text { Employer Subsidizes Parking: 1: Yes; 2: No; 8: DK; 9: RF }\end{array}$ \\
\hline BAL \& DC & $\begin{array}{l}\text { Employer Provides Subsidies for Transit/Vanpooling: 1: Yes; 2: No; -9: NA } \\
\text { Employer Provides Free Parking: 1: Yes; 2: No; -9: NA } \\
\text { Employer and Employee Share Parking Cost: 1: Yes; 2: No; -9: NA }\end{array}$ \\
\hline DEN & $\begin{array}{l}\text { Employer Provides Transit Pass at No Charge: 1: Yes; 2: No; 8: DK; 9: RF } \\
\text { Employer Provides Free Parking: 1: Yes; 2: No; 8: DK; 9: RF }\end{array}$ \\
\hline PHL & $\begin{array}{l}\text { Employer Offers to Subsidize/Pay for Part of Transit Fare: 1; Employee Must Pay for Transit Fare } \\
\text { Out-of-Pocket: 2; DK: 8; Employer Offers to Subsidize/Pay for Part of Workplace Parking: 1; } \\
\text { Employee Must Pay for Workplace Parking Out-of-Pocket; Free Parking Available for Employees; } \\
\text { 8: DK }\end{array}$ \\
\hline NY \& NJ & $\begin{array}{l}\text { Employer Transportation Benefit: 1: Toll/EZ Pass Payment or Reimbursement; 2: Public Transit } \\
\text { Payment or Reimbursement; 3: Free Parking or Reimbursement; 4: Secure Bike Parking; 5: I Do } \\
\text { Not Use Any Employer-Provided Transportation Subsidies; 7: Other Subsidies; 8: DK; 9: RF }\end{array}$ \\
\hline LA \& SD, SF & $\begin{array}{l}\text { Employer or School Pays for All or Any Part of Transit Fare: 1: Yes; 2: No; 8: DK; 9-RF } \\
\text { (only collected for those with 1 or more transit trips in prior week) }\end{array}$ \\
\hline
\end{tabular}

Prior research informed the selection of explanatory variables to include in the analysis. Income is the primary explanatory variable of interest. As referenced in the Introduction, aggregate national statistics suggest that subsidized commuting for public transport and vanpooling varies with income, with only $2 \%$ of workers in the lowest wage quartile subsidized compared to $14 \%$ of workers in the highest wage quartile (Bureau of Labor Statistics 2018, Table 40). The National Compensation Survey also suggests that part-time workers receive subsidized commuting for public transport and vanpooling at a lower rate (3\%) than full-time workers (9\%), and that workers in service occupations are subsidized at below-average rates while those in public administration and management are subsidized at above-average rates (Bureau of Labor Statistics 2018, Table 40). Employer size has also been found to be associated with benefit offerings, with large- and medium-sized employers more likely to offer transit benefits than small businesses (TransitCenter 2010; Ramfos 2017); unfortunately, employer size could not be included due to a lack of data in the travel surveys. There is also evidence that commuter benefits vary by employer type. For example, the 2016 State of the Commute regional survey for Washington, DC, found that federal workers were offered a transit or vanpooling incentive from employers at higher rates (73\%) than those who work in the private (22\%) or nonprofit (42\%) sectors, or those who work for state or local agencies (25\%) (Ramfos 2017). This aligns with a large body of scholarship that suggests fringe benefits are a strategy for closing public-private sector wage gaps (Thom and Reilly 2015). Employer-based transit subsidies are also likely to vary by employer location, due to the spatial character of transit service. TransitCenter (2010) found the share of employers offering commuter benefits to be twice as high in central business districts 
(CBDs) compared to locations outside of CBDs. Likewise, the 2016 State of the Commute regional survey for Washington, DC, found that the share of workers offered transit incentives from employers declined as distance from the regional center increased, from $57 \%$ in the region's inner core to $25 \%$ in the middle ring and $10 \%$ in the outer ring (Ramfos 2017). Prior research empirically estimating the cross-elasticity of car parking and transit subsidies is not evident, but historically many employers introduced transit benefit plans to "equalize" or "offset" car parking subsidies (Baker, Judd, and Oram 2010). A car parking subsidy may therefore be likely to increase the chance of being offered a transit subsidy if employers seek to appear fair. However, in some cases, employers might consider the two subsidies to be substitutes.

\section{Results}

This section contains the presentation of results for binary tabulations between employer-based transit benefits and income groups, as well as the binary logistic regression results. First, Figure 1 presents the binary tabulations between the share of workers offered an employer-based transit subsidy and household income as categorized by income quintiles. In each of the seven cases, the share of workers offered an employer-based transit subsidy is lowest for workers in the lowest income quintile. The share increases sequentially between the 1st and 5th income quintiles in four cases (ATL, BAL \& DC, DEN, and LA \& SD). Meanwhile, in NY \& NJ, the 2nd quintile has a higher share than the 3rd quintile, while in PHL, the 3rd quintile has the highest overall share, and in SF, the 4th quintile has the highest share. One-sided difference-in-means t-tests suggest that the mean for the 1st income quintile is significantly less than the mean for the 2 nd-5th quintiles ( $p$-values $<0.01$ ) in each of the seven cases.

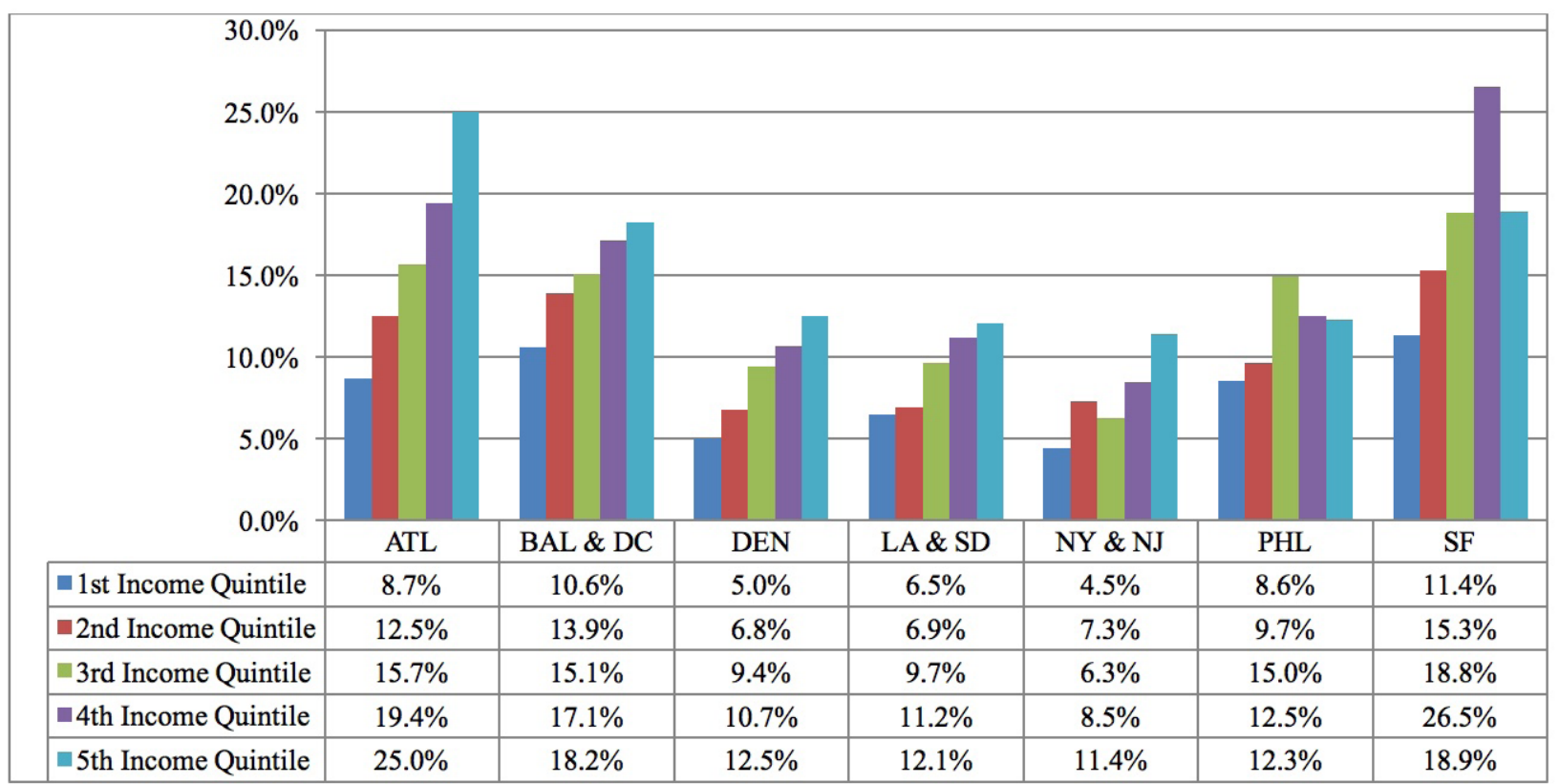

\section{FIGURE 1.}

Share of workers offered an employer-based transit subsidy by income quintile

The binary distributions presented in Figure 1 allow for other factors that may be significantly associated with employer-based transit subsidy offerings to simultaneously vary with income. As a result, binary logistic regression is used to evaluate the relationship between transit subsidy offerings and income while controlling for other potentially relevant factors. 
Table 3 summarizes sample sizes as well as several measures of goodness-of-fit for the seven individual logistic regression models used to estimate the likelihood of an employer-based transit subsidy offer. Three of the samples have 3,000-5,000 observations (LA \& SD, PHL, and SF), while two of the samples have 7,000-10,000 observations (ATL, DEN). The two largest samples are for BAL \& DC $(14,413)$ and NY \& NJ $(20,009)$. Pseudo-R^2 values range across the seven models from 0.048 (SF) to 0.258 (BAL \& DC). The Hosmer-Lemeshow goodnessof-fit test indicates there is evidence for model misspecification in four of the models (ATL, BAL \& DC, DEN, and NY \& NJ). The Link test suggests model misspecification in five of the models (ATL, DEN, LA \& SD, NY \& NJ, and $\mathrm{PHL}$ ). SF is the only case where both the Hosmer-Lemeshow and Link tests do not indicate evidence of model misspecification.

\section{TABLE 3.}

Sample Size and Measures of Explanatory Power and Model Fit (Employer-Based Transit Subsidy Offering)

\begin{tabular}{|l|r|c|c|c|c|c|}
\cline { 2 - 7 } & $\begin{array}{c}\text { Sample } \\
\text { Size }\end{array}$ & pseudo-R^2 & $\begin{array}{c}\text { Hosmer-Lemeshow } \\
\text { GOF p-value }\end{array}$ & $\begin{array}{c}\text { Link Test squared- } \\
\text { term p-value }\end{array}$ & PRE & $\begin{array}{c}\text { Concordance } \\
\text { Statistic }\end{array}$ \\
\hline ATL & 7,784 & 0.070 & 0.075 & $<0.01$ & $0.0 \%$ & 0.686 \\
\hline BAL \& DC & 14,413 & 0.258 & 0.015 & 0.343 & $16.9 \%$ & 0.839 \\
\hline DEN & 7,409 & 0.174 & 0.028 & 0.036 & $6.5 \%$ & 0.783 \\
\hline LA \& SD & 3,811 & 0.062 & 0.618 & 0.010 & $0.0 \%$ & 0.675 \\
\hline NY \& NJ & 20,009 & 0.193 & 0.001 & $<0.01$ & $0.0 \%$ & 0.824 \\
\hline PHL & 4,830 & 0.122 & 0.312 & 0.042 & $0.0 \%$ & 0.752 \\
\hline SF & 3,449 & 0.048 & 0.642 & 0.505 & $0.0 \%$ & 0.654 \\
\hline
\end{tabular}

Although each of the seven models improve upon random chance, given concordance statistics above 0.5 , the proportional reduction in error (PRE) classification statistics indicate that only two cases (BAL \& DC and DEN) reduce errors in the prediction of the outcome. As positive outcomes were relatively rare (ATL 13\%; BAL \& DC 16\%; DEN 12\%; LA \& SD 13\%; NY \& NJ 8\%; PHL 11\%; SF 18\%), the low sensitivity of the models is somewhat expected. Based on an overall assessment of the model indicators presented in Table 3, the following discussion focuses only on the results for the two cases (BAL \& DC and DEN) with nonzero PRE measures, which also have the highest and third-highest pseudo- $\mathrm{R}^{\wedge} 2$ measures.

Tables 4 and 5 present the summary statistics for BAL \& DC and DEN, respectively. As mentioned above, transit benefit offerings were relatively rare, with $16.1 \%$ of workers in the BAL \& DC sample offered a transit subsidy and $11.8 \%$ of workers in the DEN sample. Car parking subsidies were more common, with $59.4 \%$ and $88.6 \%$ of workers offered them in the BAL \& DC and DEN samples, respectively. Income quintiles for each case were created by tabulating household income categories for workers using sample weights, and then creating groups as close to quintile cutoffs as possible. As the summary statistics reveal, the income quintile groups were not equal in size, and in both cases the 1st income quintile group was the smallest in the sample. Most of the workers had either a weekday-only or typical 40-hour work schedule. Half of the BAL \& DC sample worked in private firms, while management and finance professionals had the highest representation in the DEN sample. 
TABLE 4.

Summary Statistics for the Baltimore, MD, and Washington, DC, Sample

\section{\begin{tabular}{l|l|l|l|l} 
Obs & Mean & Std. Dev. & Min & Max \\
\hline
\end{tabular}}

\begin{tabular}{|c|c|c|c|c|c|}
\hline \multicolumn{6}{|l|}{ Transportation Benefits } \\
\hline Transit Subsidy & 14,413 & 0.161 & 0.367 & 0 & 1 \\
\hline Parking Subsidy & 14,413 & 0.594 & 0.491 & 0 & 1 \\
\hline \multicolumn{6}{|l|}{ Income Group } \\
\hline 1st Income Quintile & 14,413 & 0.150 & 0.357 & 0 & 1 \\
\hline 2nd Income Quintile & 14,413 & 0.170 & 0.376 & 0 & 1 \\
\hline 3rd Income Quintile & 14,413 & 0.172 & 0.377 & 0 & 1 \\
\hline 4th Income Quintile & 14,413 & 0.202 & 0.401 & 0 & 1 \\
\hline 5th Income Quintile & 14,413 & 0.307 & 0.461 & 0 & 1 \\
\hline \multicolumn{6}{|l|}{ Schedule Type } \\
\hline Weekdays Only & 14,413 & 0.732 & 0.443 & 0 & 1 \\
\hline Weekdays \& Weekends & 14,413 & 0.239 & 0.427 & 0 & 1 \\
\hline Weekends Only & 14,413 & 0.006 & 0.078 & 0 & 1 \\
\hline Variable Schedule & 14,413 & 0.022 & 0.146 & 0 & 1 \\
\hline \multicolumn{6}{|l|}{ Employer Location } \\
\hline Arlington County & 14,413 & 0.050 & 0.219 & 0 & 1 \\
\hline Baltimore City & 14,413 & 0.091 & 0.288 & 0 & 1 \\
\hline Baltimore County & 14,413 & 0.080 & 0.271 & 0 & 1 \\
\hline Fairfax County & 14,413 & 0.129 & 0.336 & 0 & 1 \\
\hline Montgomery County & 14,413 & 0.100 & 0.300 & 0 & 1 \\
\hline Prince George's County & 14,413 & 0.073 & 0.260 & 0 & 1 \\
\hline Washington, DC & 14,413 & 0.206 & 0.404 & 0 & 1 \\
\hline \multicolumn{6}{|l|}{ Employer Type } \\
\hline For-profit Firm & 14,413 & 0.499 & 0.500 & 0 & 1 \\
\hline Non-profit Firm & 14,413 & 0.150 & 0.357 & 0 & 1 \\
\hline Federal Government & 14,413 & 0.196 & 0.397 & 0 & 1 \\
\hline State/Local Government & 14,413 & 0.150 & 0.357 & 0 & 1 \\
\hline Foreign/International & 14,413 & 0.005 & 0.073 & 0 & 1 \\
\hline
\end{tabular}

Note: Person-level sample weights are applied. 
TABLE 5.

Summary Statistics for the Denver, CO, Sample

\section{\begin{tabular}{l|l|l|l|l|} 
Obs & Mean & Std. Dev. & Min & Max
\end{tabular}}

\begin{tabular}{|c|c|c|c|c|c|}
\hline \multicolumn{6}{|l|}{ Transportation Benefits } \\
\hline Transit Subsidy & 7,409 & 0.118 & 0.322 & 0 & 1 \\
\hline Parking Subsidy & 7,409 & 0.886 & 0.317 & 0 & 1 \\
\hline \multicolumn{6}{|l|}{ Income Group } \\
\hline 1st Income Quintile & 7,409 & 0.095 & 0.293 & 0 & 1 \\
\hline 2nd Income Quintile & 7,409 & 0.114 & 0.318 & 0 & 1 \\
\hline 3rd Income Quintile & 7,409 & 0.334 & 0.472 & 0 & 1 \\
\hline 4th Income Quintile & 7,409 & 0.263 & 0.440 & 0 & 1 \\
\hline 5th Income Quintile & 7,409 & 0.194 & 0.395 & 0 & 1 \\
\hline \multicolumn{6}{|l|}{ Schedule Type } \\
\hline 1-29 Hours Per Week & 7,409 & 0.188 & 0.391 & 0 & 1 \\
\hline 30-39 Hours Per Week & 7,409 & 0.115 & 0.319 & 0 & 1 \\
\hline 40 Hours Per Week & 7,409 & 0.426 & 0.494 & 0 & 1 \\
\hline More Than 40 Hours Per Week & 7,409 & 0.271 & 0.445 & 0 & 1 \\
\hline \multicolumn{6}{|l|}{ Employer Location } \\
\hline Aurora & 7,409 & 0.071 & 0.257 & 0 & 1 \\
\hline Boulder & 7,409 & 0.078 & 0.268 & 0 & 1 \\
\hline Denver & 7,409 & 0.373 & 0.484 & 0 & 1 \\
\hline Englewood & 7,409 & 0.091 & 0.288 & 0 & 1 \\
\hline Littleton & 7,409 & 0.046 & 0.209 & 0 & 1 \\
\hline \multicolumn{6}{|l|}{ Occupational Group } \\
\hline Management \& Finances & 7,409 & 0.268 & 0.443 & 0 & 1 \\
\hline Science \& Health Professionals & 7,409 & 0.222 & 0.415 & 0 & 1 \\
\hline Professional Services & 7,409 & 0.233 & 0.423 & 0 & 1 \\
\hline Support Services & 7,409 & 0.170 & 0.376 & 0 & 1 \\
\hline Production, Extraction, Military & 7,409 & 0.099 & 0.298 & 0 & 1 \\
\hline Other & 7,409 & 0.009 & 0.095 & 0 & 1 \\
\hline
\end{tabular}

Note: Person-level sample weights are applied.

Following the summary statistics, Tables 6 and 7 present the binary logistic regression results for the BAL \& DC and DEN samples, respectively. Coefficients have been transformed into odds ratios, which in this case represent the likelihood of being offered a transit subsidy relative to the base value of 1.0 for the reference group, while controlling for other variables in the analysis. 
TABLE 6.

Binary Logistic Regression Results (Likelihood of Employer-Based Transit Subsidy) for the Baltimore, MD, and Washington, DC, Sample

\section{\begin{tabular}{l|l|l|l} 
Odds Ratio & Std. Err. & z & P $>\mathbf{z}$
\end{tabular}}

\section{Other Transportation Benefit}

\begin{tabular}{|l|r|r|r|r|}
\hline Parking Subsidy & 0.577 & 0.032 & -9.8 & 0.000 \\
\hline \multicolumn{5}{|l|}{ Income Group } \\
\hline 1st Income Quintile (Base) & & & & \\
\hline 2nd Income Quintile & 1.243 & 0.125 & 2.2 & 0.030 \\
\hline 3rd Income Quintile & 1.288 & 0.129 & 2.5 & 0.012 \\
\hline 4th Income Quintile & 1.336 & 0.132 & 2.9 & 0.003 \\
\hline 5th Income Quintile & 1.206 & 0.110 & 2.1 & 0.040 \\
\hline
\end{tabular}

\section{Schedule Type}

\begin{tabular}{|l|r|r|r|r|}
\hline Weekdays Only (Base) & & & & \\
\hline Weekdays \& Weekends & 0.651 & 0.047 & -5.9 & 0.000 \\
\hline Weekends Only & 0.231 & 0.172 & -2.0 & 0.050 \\
\hline Variable Schedule & 0.435 & 0.099 & -3.7 & 0.000 \\
\hline Employer Location \\
\hline Arlington County & 7.969 & 0.975 & 17.0 & 0.000 \\
\hline Baltimore City & 3.631 & 0.469 & 10.0 & 0.000 \\
\hline Baltimore County & 1.319 & 0.245 & 1.5 & 0.136 \\
\hline Fairfax County & 2.261 & 0.293 & 6.3 & 0.000 \\
\hline Montgomery County & 4.238 & 0.499 & 12.3 & 0.000 \\
\hline Prince George's County & 1.737 & 0.251 & 3.8 & 0.000 \\
\hline Washington, DC & 11.149 & 1.107 & 24.3 & 0.000 \\
\hline
\end{tabular}

\section{Employer Type}

\begin{tabular}{|l|r|r|r|r|}
\hline For-profit Firm (Base) & & & & \\
\hline Non-profit Firm & 1.303 & 0.100 & 3.5 & 0.001 \\
\hline Federal Government & 5.323 & 0.345 & 25.8 & 0.000 \\
\hline State/Local Government & 1.224 & 0.115 & 2.2 & 0.031 \\
\hline Foreign/International & 0.784 & 0.212 & -0.9 & 0.368 \\
\hline Constant & 0.034 & 0.004 & -27.8 & 0.000 \\
\hline
\end{tabular}

Note: Binary Outcome (1: Offered Transit Subsidy by Employer); $N=14,413$; pseudo- $R \wedge 2=0.258$; Hosmer-Lemeshow Goodness-of-Fit p-value=0.015 (fail); Link Test squared-term p-value $=0.343$ (pass); $37.5 \%$ sensitivity; $95.7 \%$ specificity; $16.9 \%$ PRE. Standard errors adjusted for clusters at the household level. 
TABLE 7.

Binary Logistic Regression Results (Likelihood of Employer-Based Transit Subsidy) for the Denver, CO, Sample

\begin{tabular}{|c|c|c|c|c|}
\hline & Odds Ratio & Std. Err. & $\mathbf{z}$ & $P>z$ \\
\hline \multicolumn{5}{|l|}{ Other Transportation Benefit } \\
\hline Parking Subsidy & 0.275 & 0.026 & -13.6 & 0.000 \\
\hline \multicolumn{5}{|l|}{ Income Group } \\
\hline \multicolumn{5}{|l|}{ 1st Income Quintile (Base) } \\
\hline 2nd Income Quintile & 1.139 & 0.251 & 0.6 & 0.554 \\
\hline 3rd Income Quintile & 1.219 & 0.232 & 1.0 & 0.298 \\
\hline 4th Income Quintile & 1.391 & 0.271 & 1.7 & 0.090 \\
\hline 5th Income Quintile & 1.696 & 0.336 & 2.7 & 0.008 \\
\hline \multicolumn{5}{|l|}{ Schedule Type } \\
\hline \multicolumn{5}{|l|}{ 1-29 Hours Per Week (Base) } \\
\hline 30-39 Hours Per Week & 1.712 & 0.318 & 2.9 & 0.004 \\
\hline 40 Hours Per Week & 2.845 & 0.404 & 7.4 & 0.000 \\
\hline More Than 40 Hours Per Week & 2.013 & 0.304 & 4.6 & 0.000 \\
\hline \multicolumn{5}{|l|}{ Employer Location } \\
\hline Aurora & 1.168 & 0.234 & 0.8 & 0.440 \\
\hline Boulder & 11.077 & 1.478 & 18.0 & 0.000 \\
\hline Denver & 2.542 & 0.297 & 8.0 & 0.000 \\
\hline Englewood & 1.065 & 0.213 & 0.3 & 0.754 \\
\hline Littleton & 0.856 & 0.275 & -0.5 & 0.629 \\
\hline \multicolumn{5}{|l|}{ Other (Base) } \\
\hline \multicolumn{5}{|l|}{ Occupational Group } \\
\hline \multicolumn{5}{|l|}{ Management \& Finances } \\
\hline Science \& Health Professionals & 1.228 & 0.130 & 2.0 & 0.051 \\
\hline Professional Services & 0.912 & 0.098 & -0.9 & 0.391 \\
\hline Support Services & 0.557 & 0.083 & -4.0 & 0.000 \\
\hline Production, Extraction, Military & 0.641 & 0.114 & -2.5 & 0.013 \\
\hline Other & 0.383 & 0.213 & -1.7 & 0.084 \\
\hline Constant & 0.068 & 0.018 & -10.1 & 0.000 \\
\hline
\end{tabular}

Note: Binary Outcome (1: Offered Transit Subsidy by Employer); $N=7,409 ;$

pseudo- $R^{\wedge} 2=0.174$; Hosmer-Lemeshow Goodness-of-Fit $p$-value $=0.028$ (fail); Link

Test squared-term $p$-value $=0.036$ (fail); $11.8 \%$ sensitivity; $99.3 \%$ specificity; $6.5 \%$ PRE.

Standard errors adjusted for clusters at the household level.

The sign for each income quintile is consistent across the two cases-all the odds ratios for the 2nd-5th income quintiles are above the 1.0 level for the 1 st income quintile base category. Using a p-value threshold of 0.10 , the odds of being offered an employer-based transit subsidy are significantly higher for those in the 2nd-5th income quintiles in the BAL \& DC sample, but significantly higher only for those in the 4th-5th income quintiles in the DEN sample. These results largely confirm the hypothesis that low-income workers are less likely to have access to employer-based transit subsidies than workers in higher income groups, even after controlling for other relevant worker and employer characteristics. 
Results for the additional explanatory factors are largely expected. The odds of being offered a transit subsidy were significantly lower for workers offered a car parking subsidy in both the BAL \& DC and DEN samples. These results provide some evidence to support the notion that the benefits may be considered substitutes, but it could also be the case that the model is attributing to the car parking variable land use characteristics associated with free parking not otherwise captured in the model through the employer location variable. Employer type information was available for the BAL \& DC sample, but not the DEN sample. In BAL \& DC, the odds ratio for federal workers was over four times the odds ratio for state/local workers, consistent with the State of the Commute regional study conducted by the DC MPO, which found much higher rates of transit and vanpooling incentives among federal workers than state or local government workers. With regard to employer location, results from both samples indicate that employer locations in large cities and regional centers tend to be significantly associated with the likelihood of being offered an employer-based transit subsidy. These findings are consistent with prior research that has found that transit benefit offerings are most common in CBDs and near regional centers. In BAL \& DC, work schedule was categorized based on combinations of weekdays versus weekends, and workers whose schedules included weekends had significantly lower odds of a transit subsidy offer compared to those working only weekdays. In DEN, work schedule was organized by hours per week, and compared to those working part-time (1-29 hours per week), all other workers had significantly higher odds of being offered an employer-based transit subsidy. In general, benefits are often limited or unavailable for parttime workers, so these findings are reasonable. Occupation information was unavailable for BAL \& DC, but in DEN, workers in support services had significantly lower odds of a transit subsidy offer. This is consistent with the below-average national rate of $5 \%$ for subsidized commuting for public transport and vanpooling reported for service sector employees (Bureau of Labor Statistics 2018, Table 40).

\section{Conclusion}

This study evaluated the likelihood of being offered employer-based transit subsidies across income groups. Binary distributions for each of the seven cases indicate that the share of workers offered an employer-based transit subsidy is lowest for workers in the lowest income quintile. Meanwhile, binary logistic regression results for the two models with the most explanatory power indicate that the odds of being offered an employer-based transit subsidy are significantly higher for workers in the 4th-5th income quintiles in both cases, but significantly higher for workers in the 2nd-3rd income quintiles in only one case. Overall, these results suggest that higher income workers are more likely to be offered employer-based transit subsidies than lower income workers, consistent with aggregate national statistics for subsidized commuting for public transport and vanpooling.

These findings may be relevant to policy makers interested in supporting affordable access to opportunities for the working poor as well as transport affordability overall. One policy strategy could be to compel more employers to offer transit benefits, with the hopes that they would become available to a higher share of the working poor. As noted, several major cities, including San Francisco, CA, Washington, DC, and New York, NY, have implemented ordinances in the past decade requiring some employers to offer commuter benefits (Grisby 2017; Dutzik et al. 2017). Commuter benefit ordinances have typically required that employers of a certain size (e.g., 20 or more employees) offer some type of commuter benefit; to the extent that income and employer size remain uncorrelated (such that the working poor would not be concentrated in employers exempt from the ordinances), commuter benefit ordinances could increase the likelihood that a low-income worker would be offered a transit subsidy. Similarly, parking cash out ordinances, such as the one under consideration in Washington, DC (Lazo 2017), could increase the likelihood of low-income workers receiving a subsidy for commuting. Parking cash out may be especially effective given the tendency for car parking subsidies to be offered at higher rates than transit subsidies (see Tables 4 and 5). The Federal Highway Administration recently 
provided funding for a study of mandates and incentives regarding parking cash out, along with pre-tax commuter benefits and parking surtaxes (Kaufman et al. 2017). However, low-income workers were offered employer-based transit benefits at significantly lower rates even in the one study case (SF) where at least one jurisdiction had a commuter benefit ordinance in place at the time of the survey collection. As a result, the impact of commuter benefit ordinances on low-income access to transit benefits remains an outstanding empirical question and deserves additional study. Another alternative could be the removal of the tax-preferred status of employer-based commuter benefits for both transit and car parking-tax expenditures tend to be regressive in nature (Weimer and Vining 1999) — paired with a dedication of the resulting revenues to the benefit of low-income workers. The creation of a commuter income tax deduction that could operate alongside existing employer-based benefits could also expand access to benefits and ensure equity for workers who do not receive employer-based benefits (Dutzik et al. 2017). Replacing rather than supplementing employerbased benefits could remove employer control over the benefits, and shift the focus away from subsidies for commuting and toward subsidies for all trip purposes; one mechanism could be federal subsidies for transit passes (Phillips 2014). Indeed, support has been growing in New York, Boston, and Denver for income-based programs similar to those already in place in Seattle (ORCA Lift) and San Francisco (Muni Lifeline) (Stolper and Rankin 2016; Mondon 2015; Dungca 2016). Most recently, funding for the "Fair Fares" initiative to subsidize MetroCards for residents living below the federal poverty line was included in a New York City budget passed in June 2018 (Neuman and Goodman 2018). Transit subsidies for all trip purposes could be especially effective at relieving the consumption versus accessibility tradeoffs that many low-income households face, and improve upon the current system of employer-based commuter benefits if they prioritize subsidies for those experiencing the greatest accessibility deficits.

This study may serve as a reference for researchers and policy makers interested in commuter benefits, distributional and equity effects, and affordable access. Pooling the household travel surveys into a single dataset for this study would have enabled greater explanatory power from a statistical standpoint, but each of the seven cases resulted in worker-level datasets that were large (at least 3,000 observations). As a result, pooling was deemed insufficiently beneficial when considered in relation to problems associated with survey format variation. For this reason, the discussion emphasized patterns across the cases, but excluded overall joint probability statements or direct comparisons about the magnitude of estimated effects. The collection of information about employer-based transit subsidies in a national survey could enable more direct comparisons across regions. The travel surveys collected binary information about employer-based transit subsidies, but not their monetary value. Future research could incorporate their monetary value if such data become available. In addition, Agrawal and colleagues (2011) note the lack of availability of travel behavior and cost information in combined datasets; typically, household travel surveys provide detailed information about travel behavior, but collect no information on transport expenditures. Such a combined dataset, as well as qualitative research techniques, could enable analysis of the impact of transit subsidies on consumption versus accessibility poverty tradeoffs. Finally, future research could focus on the underlying factors that explain why access to transit benefits is more equitable in some places than others, especially if able to draw from a national dataset that would facilitate direct comparison of the magnitude of estimated effects. Research attention is also needed to support a greater understanding of optimal policies when sustainability and equity impacts are jointly considered. What would be the impact of prioritizing transit subsidies for the working poor in terms of sustainability mode shift goals? A future analysis should assess the best policy strategies to support the goals of both affordable access for all and sustainable transport. 


\section{Acknowledgments and Disclaimer}

This paper is adapted from the author's doctoral dissertation, "A Transport Justice Evaluation of EmployerBased Transit Subsidies." During her doctoral studies, she received financial support from the US Department of Transportation's Dwight D. Eisenhower Graduate Fellowship program, as well as the Urban Affairs \& Planning program and the School of Public \& International Affairs at Virginia Tech.

MPO staff from the Atlanta Regional Commission, Baltimore Regional Transportation Board, Delaware Valley Regional Planning Commission, Denver Regional Council of Governments, National Capital Region Transportation Planning Board, and North Jersey Transportation Planning Authority provided assistance with household travel survey data inquiries.

Any opinions expressed or representations made by the author of this study are the sole responsibility of the author. The MPOs in this study (Atlanta Regional Commission, Baltimore Regional Transportation Board, Delaware Valley Regional Planning Commission, Denver Regional Council of Governments, Metropolitan Transportation Commission, National Capital Region Transportation Planning Board, New York Metropolitan Transportation Council, North Jersey Transportation Planning Authority, San Diego Association of Governments, and Southern California Association of Governments) make no warranty on the results or opinions derived from the data for this study.

\section{References}

Agrawal, A. W., E. Blumenberg, S. Abel, G. Pierce, and C. Darrah. 2011. Getting Around When You're Just Getting By: The Travel Behavior and Transportation Expenditures of Low-Income Adults. MTI Report 10-02. Mineta Transportation Institute, San José State University.

Baker, S., D. Judd, and R. Oram. 2010. "Tax-Free Transit Benefits at 30: Evolution of a Free Parking Offset." Journal of Public Transportation 13 (2): 1-22.

Bianco, M. J. 2000. "Effective Transportation Demand Management: Combining Parking Pricing, Transit Incentives, and Transportation Management in a Commercial District of Portland, Oregon." Transportation Research Record: Journal of the Transportation Research Board 1711 (1): 46-54.

Bouchard, M. 2015. "Transportation Emerges as Crucial to Escaping Poverty." The New York Times. May 7, 2015. https://www.nytimes.com/2015/05/07/upshot/transportation-emerges-as-crucial-to-escaping-poverty. html?abt=0002\&abg=1\&_r=0.

BRTB (Baltimore Regional Transportation Board). 2008. 2007/2008 Household Travel Survey. Baltimore Metropolitan Council.

Bureau of Labor Statistics. 2018. National Compensation Survey. Washington, DC: US Department of Labor.

Bureau of Transportation Statistics. 2003. "Commuting Expenses: Disparity for the Working Poor." BTS Issue Brief No. 1, March 2003. Washington, DC: US Department of Transportation.

Bureau of Transportation Statistics. 2016. Transportation Statistics Annual Report. Washington, DC: US Department of Transportation.

Clark, H. M. 2017. Who Rides Public Transportation. Washington, DC: American Public Transportation Association. 
Clifton, K., and K. Lucas. 2004. "Examining the Empirical Evidence of Transport Inequality in the US and UK." In Running on Empty: Transport, Social Exclusion and Environmental Justice, edited by Karen Lucas, 15-36. Bristol, UK: The Policy Press.

Deka, D. 2004. "Social and Environmental Justice Issues in Urban Transportation." In The Geography of Urban Transportation, edited by Susan Hanson and Genevieve Giuliano, 332-355. New York, NY: The Guildford Press.

DRCG (Denver Regional Council of Governments). 2010. "Front Range Travel Counts Survey." Denver Regional Council of Governments.

Dungca, N. 2016. "MBTA Eyes Discounts for Low-Income Riders in the Future." The Boston Globe, January 8, 2016. https://www.bostonglobe.com/metro/2016/01/07/mbta-eyes-discounts-for-low-income-riders-future/ y4KOANR1vjtWQ8vjxtYzhN/story.html.

Dutzik, T., E. Berg, A. Miller, and R. Cross. 2017. "Who Pays for Parking? How Federal Tax Subsidies Jam More Cars into Congested Cities, and How Cities Can Reclaim Their Streets." Frontier Group and TransitCenter. https://frontiergroup.org/reports/fg/who-pays-parking.

DVRPC (Delaware Valley Regional Planning Commission). 2013. 2012-2013 Household Travel Survey for the Delaware Valley Region. Philadelphia, PA: Delaware Valley Regional Planning Commission. http://www. dvrpc.org/Transportation/Modeling/Data/.

Federal Highway Administration. 2011. Summary of Travel Trends: 2009 National Household Travel Survey. Washington DC: US Department of Transportation.

Federal Highway Administration. 2017. "Metropolitan Planning Organization Database." Washington DC: US Department of Transportation.

Ferrell, C. E. 2015. The Benefits of Transit in the United States: A Review and Analysis of Benefit-Cost Studies. MTI Project 1425. Mineta Transportation Institute, San José State University.

Grisby, D. 2017. Fair Treatment: Commuters and Tax Reform. Washington, DC: American Public Transportation Association.

Hamre, A. 2018. "A Transport Justice Evaluation of Employer-Based Transit Subsidies." PhD diss., Virginia Polytechnic Institute and State University.

Jeekel, J., and K. Martens. 2017. "Equity in Transport: Learning from the Policy Domains of Housing, Health Care and Education." European Transport Research Review 9 (4): 1-13.

Kaufman, M., J. Choe, M. Grant, A. Greenberg, and S. Sethi. 2017. "Transportation Benefits of Parking Cash Out, Pre-Tax Commuter Benefits, and Parking Surtaxes." Presentation at Transportation Research Board's 97th Annual Meeting, Washington, DC.

Kuppam, A., R. Pendyala, and M. Gollakoti. 1998. "Stated Response Analysis of the Effectiveness of Parking Pricing Strategies for Transportation Control." Transportation Research Record: Journal of the Transportation Research Board 1649 (1): 39-46.

Lazo, L. 2017. "D.C. Wants Employers to Pay Workers Not to Drive to Work." The Washington Post. March 17, 2017. https://www.washingtonpost.com/news/dr-gridlock/wp/2017/03/17/d-c-wants-employers-to-payworkers-not-to-drive-to-work/?utm_term=.3194ada9e851. 
Litman, T. 2018. Evaluating Transportation Diversity: Multimodal Planning for Efficient and Equitable Communities. Victoria Transport Policy Institute, Victoria, BC.

Mondon, M. 2015. "Denver Activists Push for Income-Based Bus Fares." NextCity. November 23, 2015. https:// nextcity.org/daily/entry/income-based-bus-fare-denver-bus-fare-increase-2016.

NCRTPB (National Capital Region Transportation Planning Board). 2010. 2007/2008 TPB Household Travel Survey. Metropolitan Washington Council of Governments.

Neuman, W., and J. D. Goodman. 2018. "New York City’s $\$ 89$ Billion Budget Includes Discount Transit Fare Plan." The New York Times. June 11, 2018. https://www.nytimes.com/2018/06/11/nyregion/new-york-city-budgetsubway-fares.html.

NREL (National Renewable Energy Laboratory). 2017. Transportation Secure Data Center. https://www.nrel.gov/ transportation/secure-transportation-data/.

NYMTC (New York Metropolitan Transportation Council). 2014. 2010/2011 Regional Household Travel Survey. https://www.nymtc.org/DATA-AND-MODELING/Travel-Surveys/2010-11-Travel-Survey.

Phillips, S. 2014. "End the Transit Commuter Benefit, And Replace It With This" (blog), Planetizen. January 24, 2014. https://www.planetizen.com/node/67154.

Ramfos, N. W. 2017. "2016 State of the Commute Survey Report." Commuter Connections. Washington, DC: Metropolitan Washington Council of Governments.

Root, A. 2001. "Can Travel Vouchers Encourage More Sustainable Travel?" Transport Policy 8 (107-114).

Sanchez, T., M. Brenman, J. Ma, and R. Stolz. 2007. The Right to Transportation: Moving to Equity. Chicago, IL: American Planning Association.

Segelhorst, E., and L. Kirkus. 1973. "Parking Bias in Transit Choice." Journal of Transport Economics and Policy 7 (1): 58-70.

Shoup, D. 2005. Parking Cash Out. Chicago, IL: American Planning Association.

Stolper, H., and N. Rankin. 2016. The Transit Affordability Crisis: How Reduced MTA Fares Can Help Low-Income New Yorkers Move Ahead. Community Service Society, New York, NY.

Thom, M., and T. Reilly. 2015. "Compensation Benchmarking Practices in Large U.S. Local Governments: Results of a National Survey." Public Personnel Management 44 (3): 340-355.

Tomer, A. 2011. "Transit Access and Zero-Vehicle Households." Metropolitan Infrastructure Initiative Series and Metropolitan Opportunity Series. The Brookings Institution, Washington, DC.

TransitCenter. 2010. 2010 Commuter Benefit Impact Survey. TransitCenter, New York, NY.

Washbrook, K., W. Haider, and M. Jaccard. 2006. "Estimating Commuter Mode Choice: A Discrete Choice Analysis of the Impact of Road Pricing and Parking Charges." Transportation 33 (6): 621-639.

Weimer, D., and A. Vining. 1999. Policy Analysis: Concepts and Practice. Third Edition. Upper Saddle River, NJ: Prentice Hall.

Willson, R., and D. Shoup. 1990. "Parking Subsidies and Travel Choices: Assessing the Evidence." Transportation 17 (2): 141-157. 


\section{About the Author}

Andrea Hamre, PhD (ahamre@gmail.com) completed the Planning, Governance, and Globalization doctoral program in the School of Public \& International Affairs at Virginia Tech. She earned a master's degree in Applied Economics from Virginia Tech and a bachelor's degree in Environmental Studies from Middlebury College. She is a member of the Transportation Research Board's Public Transportation Marketing and Fare Policy Committee. Her research interests include commuter benefits, transport justice, and sustainability. 